\author{
HARMATTA JÁNOS
}

\title{
AUGEWAS DAMOKOROS
}

\begin{abstract}
A mykenei da-mo-ko-ro (*damokoros) méltóságnév a lineáris B dokumentumok alapján következtetve a királyi palota egyik magas méltóságviselőjének volt a megnevezése, akinek feladatköre magában foglalta többek közt az élelmiszerek szétosztását a királynak dolgozó lakosság között. A Ta 711 táblán szereplő Augewas damokoros azonos lehet a görög epikus hagyomány Augewas királyával, aki Neleusszal vetélkedett a Pylos feletti uralomért.
\end{abstract}

A pylosi Ta 711 jelzetú tábla, amely a többi Ta jelú táblának bizonyos értelemben bevezetése vagy címzése lehetett, már korán magára vonta a kutatás figyelmét.

Szövege a következő:

1. sor o wi-de $\mathrm{pu}_{2}$ ?-ke-qi-ri o-te wa-na-ka te-ke *85-ke-wa da-mo-ko-ro

2. sor qe-ra-na wa-na-se-wi-ja qo-u-ka-ra ko-ki-re-ja HYDRIA 1 qe-ra-na a-mo-tewi-ja ko-ro-no-we-sa

3. sor qe-ra-na wa-na-se-wi-ja ku-na-ja qo-u-ka-ra to-qi-de-wa-sa HYDRIA 1

A szöveg írásképének értelmezése:

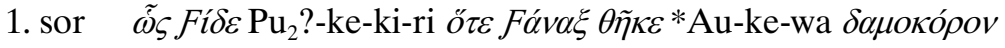

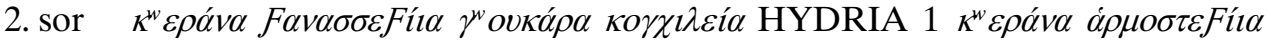

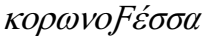

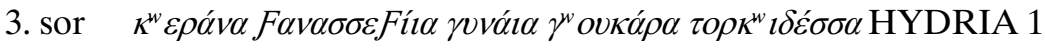

A szöveg fordítása:

1. sor Így tartott szemlét $\mathrm{Pu}_{2}$ ?-ke-qi-ri, amikor a király *Au-ke-wát damokoros-szá tette:

2. sor vizeskorsó, a királynői készletból, bikafejes, kagylóval díszített, vizeskorsó 1 vizeskorsó, a harmosteus készletéből, görbe fogóval, 
3. sor vizeskorsó, a királynői készletből, asszonyi, bikafejes, spiráldíszes, vizeskorsó $1 .{ }^{1}$

Mint látható, a táblán egy edénykészlet felsorolásáról van szó, amelyet a többi Ta jelû́ táblán még más értékes tárgyak követnek. Ezeket megszemléli - nyilván ellenôrzés céljából - $\mathrm{Pu}_{2}$ ?-ke-qi-ri abból az alkalomból, hogy a király *85-ke-wát damokoros-szá nevezte ki. A szövegösszefüggés itt nem ad biztos támpontot sem a da-mo-ko-ro íráskép biztos értelmezéséhez, sem a szó jelentésének megnyugtató meghatározásához. Ezért érthetô, ha később L. R. Palmer azt az elgondolást fejtette ki, hogy a Ta jelú táblákon egy sír mellékleteinek leltárával van dolgunk, s hogy a halott egy kétnevú személy volt, aki második névként a da-mo-ko-ro Damoklos nevet viselte $\mathrm{s}$ akinek temetésénél $\mathrm{Pu}_{2}$ ?-ke-qi-ri királyi tisztviselô a sírmellékleteket ellenórizte. ${ }^{2}$ Késóbb azonban Palmer feladni kényszerült ezt az elméletet, mert közben J. P. Oliviernek sikerült több knossosi táblatöredéket összeilleszteni, s ebből kiderült, hogy a da-mo-ko-ro szót olyan szövegösszefüggésben használták, mint a du-ma

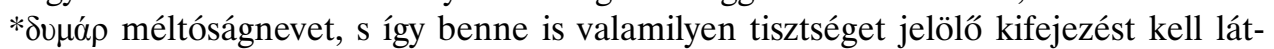
nunk. ${ }^{3}$ Egy másik újonnan összeillesztett knossosi táblán (C 7058 + X 7922) disznók szétosztásáról van szó bizonyos személyek között a da-mo-ko-ro részéről. Egy harmadik, töredékekből összeillesztett knossosi táblán (L642 + 5950) a da-mo-ko[ro] szó egy felsorolás végén fordul elő, amely különbözó anyagok és tárgyak - köztük gyapjú és fegyverek - szétosztását sorolja fel. Ebben a szövegösszefüggésben mint egyébként az elóbb említett táblákon is - a da-mo-ko-ro kifejezés szemmel láthatólag aláírásként vagy ellenjegyzésként szerepel.

Ezek a da-mo-ko-ro szóra vonatkozó újabb adatok valószínúvé teszik, hogy e méltóságnév a pylosi Ta 771 jelzetú táblán is ugyanabban a funkcióban szerepel, mint az említett knossosi táblákon. Ebben az esetben a da-mo-ko-ro megjelölés mögött valamiféle kincstárnokot, raktárfőnököt vagy a királyi palotagazdaság intézőjét kell látnunk. Így az egész Ta jelú táblasorozatot mint átadási jegyzőkönyvet értelmezhetjük. A Fóva $\xi$ *85-ke-wát kinevezte da-mo-ko-ro-nak s ez alkalommal megbízottja, $\mathrm{Pu}_{2}$ ?-ke-qi-ri megszemlélte (ellenőrizte) a da-mo-ko-ro-ra bízott értéktárgyakat s azokról jegyzókönyvet készíttetett.

Ugyanezt a jelentésfunkcióját tehetjük fel a da-mo-ko-ro méltóságnévnek utolsóként említendố előfordulásában. A híres pylosi On 300 jelzetû́ tábláról van szó, amely ismét valamilyen anyag, feltehetőleg ökörbőrök vagy esetleg levágott és kibelezett ökrök szétosztásáról szóló feljegyzésnek tekinthető.

\footnotetext{
${ }^{1}$ M. Ventris—J. Chadwick: Documents in Mycenaean Greek. Cambridge 1956. 335.

${ }^{2}$ L. R. Palmer: The Interpretation of Mycenaean Greek Texts. Oxford 1963. 340.

${ }^{3}$ L. R. Palmer: Mycenaeans and Minoans. ${ }^{2}$ London 1965. 106, 107, 161.
} 
E tábla szövege a következő:

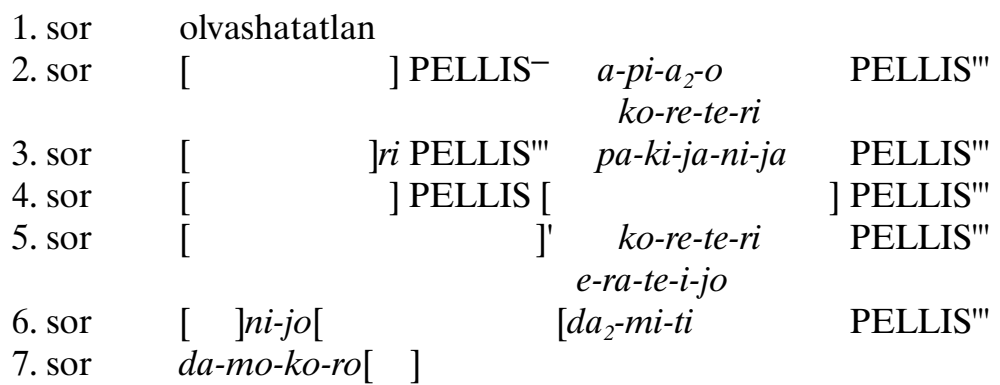

A szöveg írásképének értelmezése:

\begin{tabular}{|c|c|c|c|}
\hline 2. sor & ] PELLIS- & 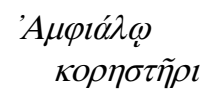 & PELLIS"' \\
\hline 3. sor & ]ri PELLIS"' & $\Sigma \varphi \alpha \gamma l \alpha v_{i} \alpha$ & PELLIS"' \\
\hline 4. sor & ] PELLIS [ & ] PELLIS"' & \\
\hline 5. sor & ]$^{\prime}$ & 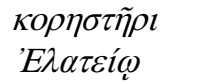 & PELLIS"' \\
\hline 6. sor & & dea - -mi-ti & PELLIS"' \\
\hline
\end{tabular}

A tábla szövegében szemmel láthatólag valamilyen területi felosztás jelenik meg, amennyiben a feljegyzés helységeket vagy körzeteket sorol fel, amelyeknek

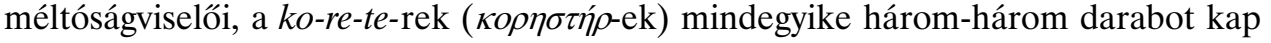
a szóban forgó anyagból. Habár a tábla közvetlenül a da-mo-ko-ro szó után sérült, nem lehet mégsem kétséges, hogy e tisztségviselő nem tartozik a szétosztott anyagban részesülők közé. Az egyes tételeket ugyanis pontosan egymás alá írták, az a hely azonban, ahová a szétosztott anyag mennyiségét kellett volna írni, a da-mo-ko-ro esetében üresen maradt. Így tehát a da-mo-ko-ro szó ezen a táblán is szemmel láthatólag aláírásként vagy ellenjegyzésként szerepel, azaz nyilvánvalóan azt a felelős személyt jeleníti meg, akinek utasítására és felelősségére az ökörbőrök vagy a levágott ökrök szétosztását foganatosították.

$\mathrm{Az}$ ismertetett adatok és értelmezésük alapján kézenfekvő arra gondolni, hogy a da-mo-ko-ro méltóságnév mind Pylosban, mind Knossosban a királyi palota egyik magas méltóságviselőjének volt a megnevezése, akinek feladatköre magába foglalta többek között az élelmiszerek és a mezőgazdasági termékek szétosztását. Ezt a következtetést egy eddig figyelmen kívül hagyott dokumentum csoport is megerósíti.

Jól ismertek, de több tekintetben még mindig homályos értelmúek azok a pylosi táblák, amelyek egy-egy munkáscsoportot és gyakran bizonyos élelmiszermeny- 
nyiségeket említenek. Ezekre például idézhetjük a pylosi Ab 27 jelzetú táblát: ${ }^{4}$

$$
\begin{array}{lll}
\text { pu-ro re-wo-to-ro-ko }<\text { MULIER }>37 \text { ko-wa } 13 \text { ko-wo } 15 & \text { TRITICUM } & \text { II T I } \\
& \text { FICUS } & \text { II T I } \\
& \text { TA DA }
\end{array}
$$

A szöveg írásképének értelmezése:

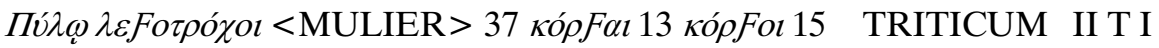

$$
\begin{aligned}
& \text { FICUS II T I } \\
& \text { TA DA }
\end{aligned}
$$

A szöveg fordítása:

Pylosban: fürdőalkalmazottak <asszonyok> 37, leányok 13, fiúk 15 búza 13321.

füge 13321

TA DA

E táblák megértéséhez itt csak annyit kell megjegyezni, hogy semmi okunk sincs arra, hogy az ezeken a táblákon feltüntetett munkásokban rabszolgákat vagy elfogott szökevényeket lássunk. ${ }^{5}$ Ellenkezőleg, minden amellett szól, hogy ezek a pylosi királyság félszabad lakosságát képviselik, akiket időről időre különböző munkák elvégzésére igénybe vettek. A munka időtartamára ezek a munkások a királyi palotától ellátásban részesültek. A búzának és a fügének az idézett táblaszövegben feltüntetett mennyisége hozzávetőleg egy havi ellátásnak felel meg. Ezekhez a dokumentumokhoz a legközelebbi párhuzamot a persepolisi kincstári táblák ${ }^{6}$ szolgáltatják, azzal a különbséggel, hogy Persepolisban a kincstári táblák tanúbizonysága szerint az ellátás csak részben volt természetbeni, részben azonban ezüsttel történt.

E pylosi táblákkal kapcsolatban megoldatlan az a kérdés, hogyan értelmezhetốk a rejtélyes TA és DA rövidítések. A szövegösszefüggés ezen a helyen, a felsorolás végén, nyilvánvalóan az élelemellátásért és a kiosztásáért felelős hivatalos személyek feltüntetését követeli meg, mint ez a lineáris B írásos táblák rövidítéseivel foglalkozó tudományos irodalomban már korábban fel is merült. ${ }^{7}$ A persepolisi kincstári táblákon ebben a szövegösszefüggésben a kincstárnok és a raktárfőnök szerepelnek. Kézenfekvő, hogy a pylosi táblák hasonló szövegösszefüggésében is ugyanilyen vagy hasonló tisztségviselóket keressünk. Így magától kínálkozik a DA rövidíté-

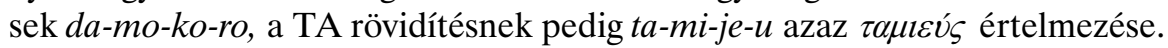

\footnotetext{
${ }^{4}$ M. Ventris-J. Chadwick: i. m. 160.

${ }^{5}$ Mint F. J. Tritsch gondolta: The Women of Pylos. Minoica. Berlin 1958. 406 skk.

${ }^{6}$ G. G. Cameron: Persepolis Treasury Tablets. Chicago é. n.

${ }^{7}$ A. Sacconi: Syllabica signa quae in inscriptionibus Mycenaeis compendiorum vice adhibentur et ideogrammatum officio aliquando funguntur. Atti e memorie del $1^{\circ}$ Congresso di Micenologia Roma 27
} settembre - 3 ottobre 1967. Roma 1967. 475, 477. 
A da-mo-ko-ro szónak ezt az értelmezését egy pontos párhuzam még inkább megerősíti. Az óperzsa királyi palotagazdaságban külön tisztségviselő múködött a munkaszolgálatra mozgósított vidéki lakosságnak juttatott élelemellátás szétosztására. Ez a piQvabaga- „élelemadag-szétosztó” méltóságnevet viselte. ${ }^{8} \mathrm{Ha}$ az Óperzsa Birodalom óriási kiterjedésének megfelelően az óperzsa államszervezet fejlettebb és differenciáltabb is lehetett, egy hasonló, de talán kevésbé specializált funkciójú méltóságviselôvel a pylosi és a knossosi királyi palotagazdaságban is bizonyára számolnunk kell.

A da-mo-ko-ro méltóságnév nyelvi magyarázatára számos elgondolás merült fel. Ezeknek a javaslatoknak gondos kritikai szúrését A. Heubeck végezte el, ${ }^{9} \mathrm{~s}$ világosan kimutatta, hogy mindezek közül csak két magyarázat jöhet számításba: 1)

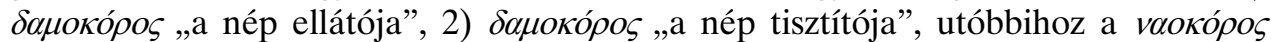
„templomtakarító, templomgondnok” tisztség kínál párhuzamot. A méltóságnév fentebb meghatározott funkciója alapján azonban kétségtelen, hogy a két magyará-

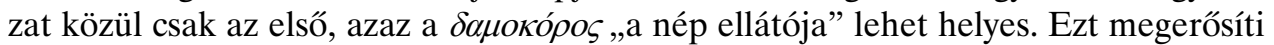

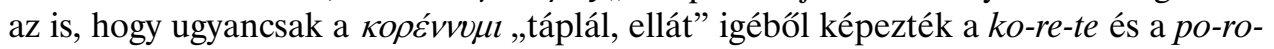
ko-re-te méltóságneveket. Ezek közül az elsô az On 300, a Jn 09 és a Kn 01 jelzetú pylosi táblák szövegösszefüggése alapján ítélve a da-mo-ko-ro-nak alárendelt tisztviselőt, a második pedig ennek a helyettesét jelölhette. ${ }^{10}$ Így ennek figyelembe vételé-

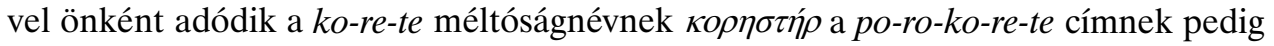

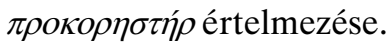

Ha e magyarázatokat az esetleg még később elôkerülő újabb adatok is megerósítik, akkor ezek révén értékes támpontokat nyerünk a mykenei társadalom szerkezetének megítéléséhez. Már korábban is feltúnt, hogy a mykenei földtulajdonviszonyok feltúnően egyeznek az ókori keleti államokéval, ${ }^{11}$ különösen ahogy azok a

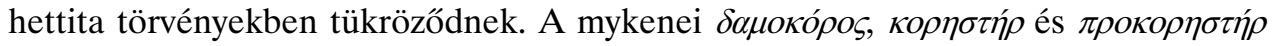
méltóságnevek most lehetővé teszik ezeknek a megfigyeléseknek továbbfejlesztését és történeti kiértékelését.

Végül felmerül még az a kérdés, maradt-e valamilyen emléke a mykenei

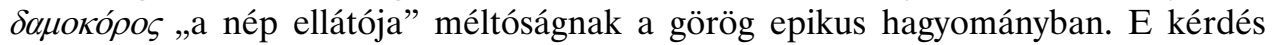
felvetése kétségtelenül jogos, mert az utóbbi évtizedek kutatásai világosan bebizonyították, hogy az epikus hagyomány számos történeti személyiség és esemény emlékét órizte meg - elég ebben az összefüggésben most csak Alexandros és Mopsos történeti szereplésére utalnunk, nem beszélve arról, hogy az eposzban a mykenei kor

${ }^{8}$ Cf. W. Eilers: Iranische Beamtennamen in der keilschriftlichen Überlieferung. I. Leipzig 1940. 59 skk., W. Brandenstein - M. Mayrhofer: Handbuch des Altpersischen. Wiesbaden 1964. 140; R. N. Frye: The History of Ancient Iran. München 1984. 110, aki azonban tévesen rekonstruálja a méltóságnevet *pa opabaga alakban.

${ }_{9}^{9}$ A. Heubeck: Zu mykenischen Namen und Titeln. IF 64 (1959) 119 skk. és Da-mo-ko-ro. Atti e memorie del $1^{\circ}$ Congresso di Micenologia Roma 27 settembre - 3 ottobre 1967. Roma 1967. 209 skk.

${ }^{10}$ M. Ventris-J. Chadwick: i. m. 357, 397.

${ }_{11}$ M. Ventris-J. Chadwick: i. m. 233-239. 
számos szakkifejezése is megôrződött. ${ }^{12}$ Ebben a vonatkozásban különösen az Ilias egyik helye (A 231) érdemel figyelmet, ahol Achilleus Agamemnonnal veszekedve szemére veti Mykene királyának:

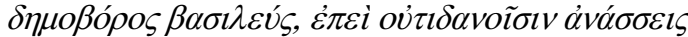

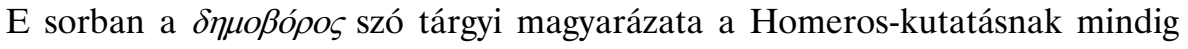
bizonyos nehézséget okozott. Ha azonban most tudjuk, hogy a mykenei királyságban

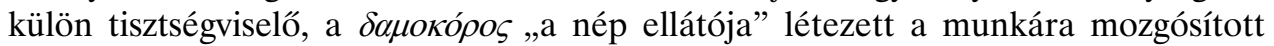

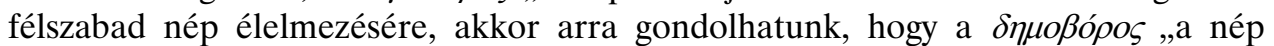

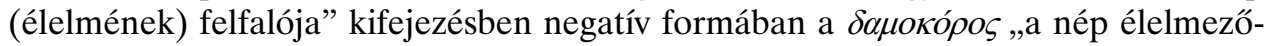
je" mykenei intézményének emléke ôrződött meg.

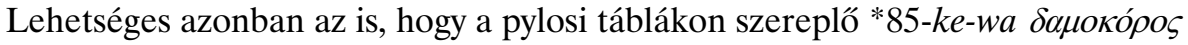
személyével kapcsolatban a történeti emlékezésnek még további lehetőségével is számolhatunk. A *85-ke-wa személynévben a meghatározatlan hangértékú *85 írásjelet Ventris és Chadwick kísérletképpen elóször, si-nek, az egész nevet pedig Sigewas-nak olvasta. ${ }^{13}$ Később azonban M. D. Petruševskinek sikerült valószínúsítenie, hogy a *85 írásjel hangértéke au, az egész név helyes olvasata pedig Augewas, s ezt az eredményt M. Lejeune alapos kutatásai is megerősítették. ${ }^{14}$ Volt azonban Petruševskinek egy további javaslata is, és pedig az, hogy Augewas damokoros azonos a Herakles-mítosz Augewas királyával, akinek az istállóit Heraklesnek a trágyától meg kellett tisztítania. Ennek megfelelóen a damokoros méltóságnév második elemét is a $\kappa о \rho \varepsilon ́ \omega$ „tisztít, kisöpör, kitakarít” igéból származtatta. Ez az elgondolás azonban, amely a Herakles-mítoszt a történeti valóság szintjére emelte át, nem részesült kedvező fogadtatásban.

Kétségtelen azonban, hogy Augewas nemcsak a Herakles-mítosztban szerepel, hanem szerves része az epikus hagyománynak is, amelyben mint Neleus ellensége jelenik meg. ${ }^{15}$ Neleus és a Neleidák viszont az újabb kutatások alapján történeti személyiségeknek tekinthetôk. ${ }^{16}$ Így joggal lehet arra gondolni, hogy az epikus hagyományban Neleus ellenségeként fennmaradt Augewas azonos a pylosi táblákon

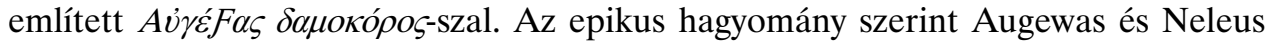

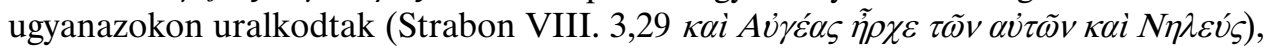
ami a későbbi íróknak nehezen megoldható problémát is okozott. Minthogy a pylosi táblák szerint Augewas nem király, hanem damokoros volt, ezt az ellentmondást azzal a feltevéssel oldhatjuk fel, hogy Augewas eredetileg Neleus királyságának leg-

\footnotetext{
${ }^{12}$ J. Chadwick: Mycenaean Elements in the Homeric Dialect. Minoica. Berlin 1958. 116 skk. ${ }_{13}$ M. Ventris-J. Chadwick: i. m. 335.

${ }^{14}$ M. Lejeune: Syllabaire mycénien: peut-on lire AU- pour 85-? SMEA 1 (1966) 9 skk.

15 Cf. Strabon VIII. 3,29.

${ }^{16}$ L. az erre vonatkozó adatokra és irodalomra Szádeczky-Kardoss Samu: Kisázsia görög gyarma-
} tosítása és a pylosi táblák. Ant. Tan. 8 (1961) 264 skk. 
főbb gazdasági intézője, damokoros-a volt, aki később függetlenítette magát királyától, s ez volt az oka az ellenséges viszonynak közte és a Neleidák között. Így a pylosi táblák segítségével az epikus hagyomány történeti hitelessége valószínúleg egy újabb ponton igazolható.

\section{SUMMARY}

On the basis of the Mycenaean documents written in Linear B, the official title da-mo-ko-ro ( ${ }^{*}$ damokoros) might have been the name for a high official of the royal palace whose task was to distribute the provisions among the people working for the king. Augewas damokoros mentioned on the tablet Ta 711 may be the same historical person as king Augewas of the Greek epic tradition who rivalled Neleus in the rule over Pylos. 